\title{
COMPUTING TERMINOLOGY
}

\author{
L'udovít POLČIC
}

\section{SLOVNÍK POČÍTAČOVÉ TERMINOLOGIE}

(Arnold Burdett, Diana Burkhardt, Aline Cumming and others: A Glossary of COMPUTING TERMS, Pearson Education, 2002, 379 p. ISBN 0201776294)

Nowadays almost everyone has some computer skills but people cannot usually use computing terms properly and even does not understand some of them. Therefore this glossary can help you understand computing terms which we meet in our everyday life and we are not certain how to understand them. On the other hand, there are also terms which are not so clear to ordinary user and need to be mentioned.

This glossary explains 3000 computing terms which are not managed as a list in alphabetical order. Related terms are logically structured in a way that definitions are easily understood. Those terms cover the whole of basic Computer Science and IT. This glossary is useful for university and college students as well as for professions which work with computers.

The text is structured into four themes:

- how computer systems are used; - what they are made of;

-how they are developed; - how they work.

The text also includes 40 detailed instructions to sections and explains how terms can be used. It also allows quick access to terms, guides the reader to related terms, it is indexed and contains a list of abbreviations and acronyms.

The first, part A (How computer systems are used) takes a general look into basic computing terms regarding data and word processing, spreadsheets, databases, graphics and design, modeling and simulation and Internet. Some sections use terms which are placed in other parts and explained there but I would say that it does not make any difficulties to understand it. Some sections in this part include figures, like section Spreadsheets which makes understanding more approachable.

The second, part B (What computer systems are made of) includes sections like types of computer, input and output, memory and communications components. At the beginning there is a general description of the main terms and there is also a list of related terms and figures for detailed explanation.

The third part, part C (How computer systems are developed) covers topics as systems design and life cycle, describing systems, programming (Flow of execution, Subprograms), program syntax and implementing, testing and running programs, data representation and managing data. Again it explains the terms at the beginning, then shows how to use related terms. In a section Programming languages gives a list of them which is quite pleasant.

The last part, part D (How computers work) consists of sections like systems software, machine architecture, interfaces and buses, physical components, communications technology, truth tables and logic gates. Especially this part is full of examples and figures for easy comprehension.

At the end of the book there is a last part $\mathrm{E}$ where is a list of abbreviations and acronyms which may be met. What I found a positive was the fact that after each abbreviation or acronym and its explanation, there was mentioned a number of page where it was mentioned. After this list, there is the index of words, so anyone can easily find or come back to a term which he had read before or finds it for the first time.

To sum up, this book is well organized with lots of examples, the parts are well-named which makes searching easier. As I said before, everyone from student to teacher or just ordinary user can find in this glossary what he needs. The fact that it is tenth edition says it itself that you will find this glossary useful in everyday life.

\author{
PaedDr. Ludovít Polčic, PhD. \\ Katedra techniky a technológií \\ Fakulta prírodných vied, UMB \\ Tajovského 40, 97401, Banská Bystrica, SR \\ Tel: +421484467217 \\ E-mail: polcic@fpv.umb.sk
}

